\section{H. Frøyshov svarer:}

Vi er åpenbart enige om mye. Herunder at slagpasienter ikke skal vente unødig på riktig behandling, at slagenhetens gode effekt er godt dokumentert, at vi må fremskaffe ny kunnskap, og at når det er indisert skal pasienten få trombolytisk- (og annen nyttig) behandling raskest mulig.

Jeg er overrasket over at innholdet i kommentaren til dels er helt løsrevet fra budskapet i lederen. At jeg ikke diskuterer trombektomi ser ut til å provosere. Det var et bevisst valg, og i første avsnitt vises det til at nye behandlingsmetoder er diskutert annet sted (1). Hovedbudskapet i lederen er mer overordnet og handler om prioritering til beste for pasienten.

Noe av uenigheten som fremkommer i kommentaren kan skyldes at vi bruker begrepet «akuttfasen» forskjellig. Retningslinjen (2) definerer akuttfasen som den første uken etter symptomdebut. Flere miljøer (3) deler forløpet i hyperakutt fase (0-12t), akutt fase (72t) og subakutt fase (til utskrivelse fra slagenhet). Jeg har forholdt meg til disse i lederen. Kommentarforfatterne ser ut til å referere til akuttfasen som den første delen av den ovenfor definerte hyperakutte fasen.

På noen områder har kommentarforfatterne åpenbart annet ståsted enn undertegnede. Å endre organiseringen av god hjerneslagbehandling i Norge (4) på grunnlag av «sydende entusiasme i verdens hjerneslagmiljø») uten at det er godt dokumentert at det samlet vil gi økt nytte, vil jeg holde for uetisk.

Indremedisinere er vant med akutte tilstander. Det kan være forskjellig alvorlighetsgrad/hastegrad mellom og innenfor tilstandene. Å dele inn pasienter eller sykdommer i fremre og bakre klasser mener jeg er en dårlig idé. En typisk hjerneslagpasient er eldre med andre indremedisinske/geriatriske tilstander samtidig. Det akutte hjerneslaget kan være det minste problemet legen må håndtere. Dagens pasientpopulasjon, den medisinskfaglige utviklingen og forventingene til helsetjenesten krever at vi har både spiss og bred kompetanse, og at vi utnytter den kompetansen som er tilgjengelig.

Tolkningen av mitt utsagn om fremtidens slagleger viser at budskapet om ensidig fokus på «high-tech og blålys» er høyaktuelt. Hovedpoenget var at utfordringen ligger i å også kunne bygge videre på mindre spektakulære metoder for å kunne tilby den beste behandlingen.

Mitt formål var å fremme en sunn og bred debatt om hjerneslag og prioritering - nettopp for at pasienter skal få tilgang til god og kunnskapsbasert behandling, både av nytt og gammelt og med bidrag fra alle relevante fagfelt. Kommentaren har bidratt til denne debatten, og jeg takker for det.

\section{Hanne Frøyshov}

hanne.froyshov@unn.no

Hanne Frøyshov (f. 1967) er overlege ved medisinsk avdeling UNN-Harstad.

Ingen oppgitte interessekonflikter.

\section{Litteratur}

1. Wyller TB, Frøyshov H, Vatn S et al. Tema: Hjerneslag. Indremedisineren 2014 2: $20-41$

2. Indredavik B, Salvesen $\mathrm{R}$, Næss $\mathrm{H}$ et al. Nasjonal retningslinje for behandling og rehabilitering av hjerneslag. Oslo: Helsedirektoratet, 2010.

3. Indredavik B. Standardisert pasientforløp: Hjerneslag. Behandling slagenhet. (v. 1.2)

4. OECD. Health at a Glance 2013: OECD Indicators. OECD Publishing.

\section{RETTELSE}

Egenkontroll av warfarinbehandling

Una Ørvim Sølvik, Elisabeth Sellevoll Løkkebø, Ann Helen Kristoffersen, Anne Vegard Stavelin, Stein Binder, Sverre Sandberg

Tidsskr Nor Legeforen 2015; 135: 849-53

I Tidsskriftet nr. 9/2015, tabell 3 s. 852 skal det i fotnote 2 stå: Det var ingen signifikant forskjell i ekstremverdier mellom opplæring i egenkontroll og egenkontroll

Vi beklager feilen, den er rettet på nett. 